\title{
10 2078/1978. Anticipation and the contemporary
}

\author{
Jamie Brassett and John O'Reilly
}

What a future!

Friedrich Nietzsche, letter to Rohde, 15 November 1874

\section{Introduction}

In 2018 we were asked to anticipate 2078 for a piece that provided some form of foresight into that world-to-come (Brassett and O'Reilly, 2018b). We, fairly obviously to us but maybe a little perversely, chose to look first to 1978 , to a moment of our teenage/proto-teenage years and punk/new wave. This was not so much a choice driven by some theoretical framework or other, but one that was stylistic: a trope that allowed us into the world of 2078. The 78 as a node joining different narratives, trends and affects. These 78 s (and all the others) will always be connected, we thought, even if different flows spill through the tracks. As we are familiar with the work of philosopherpsychoanalyst couple Gilles Deleuze and Félix Guattari, we found a similar energetics informing their joint writings: especially the second volume of their 'Capitalism and Schizophrenia' series, A Thousand Plateaus (1988); and, in that text, particularly their opening 'Introduction: Rhizome' (pp. 3-25). Here, Deleuze and Guattari are resolutely more than individuals collaborating. Their opening words are: 'The two of us wrote Anti-Oedipus together. Since each of us was several, there was already quite a crowd' (Deleuze and Guattari, 1988, p. 3). They crowd and spread through their text - though, to say 'their text' undermines their desire to create an open-ended, multiplicity of a book - rambling through works, disciplines and loves, creating philosophical concepts as they go. Most importantly for us, now, is their choice to attach dates to each of the chapters ${ }^{1}$ (apart from their introduction and conclusion). So, for example, Chapter seven is 'Year Zero: Faciality' and Chapter eleven is '1837: Of the Refrain' (Deleuze and Guattari, 1987, pp. 167-191, 310-350). ${ }^{2}$ For them, the date gives a specific moment at which the concepts they put into play intensify strongly and are able to communicate as pure a sense of themselves as possible. Their dates are barbed, sticky, seed-like forms that serve to attach concepts to those of us passing by. Similarly, then, do we offer 2078 and 1978 to locate our sense of contemporary in relation to anticipation, in a way that is also 
anticipatory: 1978 opens a way into the future and 2078 provides an anticipation for the present.

Our main concern then, in this chapter, is to present a conceptualization of the contemporary as conducted by philosopher Giorgio Agamben (2008) in such a way that it can serve as a model for acts of anticipation; and to do so in a way that emphasizes their ontologies and creativity. Here both contemporary and anticipatory positions characterize attitudes, ways of being that encounter and enhance both. That is, the ontological state of being contemporary can provide a model for the anticipator to use to adopt their stance, as Riel Miller (2011) argues should be done with the scenario planner. This is our central argument. Our chapter will develop this by first reimagining 1978 in relation to a song by The Boomtown Rats (1978) called She's So Modern. This is not only to find a way into the future that 2078 announces - and we will explain how this heading to the past allows us to do this - but also to encounter a historical moment we can use to 'clear the ground' upon which to anticipate. Our next move will be to look at an essay on the concept of contemporary, as an ontological category, in an essay by Agamben (2008). This is valuable because of its proximity to Nietzsche's concept of the 'untimely' (1997), particularly as he uses it to locate a position in relation to history. For Nietzsche, someone who is untimely has a creative use of history in order to build a new future in the present. We will conclude by bringing these thoughts back to anticipation.

\section{8 and so on}

Teenagehood is the moment at which the structures and givens of foresight already embedded in the world first clash with emergent ontologies of anticipation. How is this so? For teenagers - who occupy an emergent state of becoming characteristic of the transition from childhood to adulthood - anticipation is their mode of engagement with the world. Moreover, it is into that moment of anticipation that adults and grown-up culture give the teenager lessons in foresight, knowledge and the future: what they need to study in order to give the examiner what is expected in exams; what kinds of subjects they should be studying in university in order to be successful; what they should expect as they head out into the adult world of organizations and work; what not to take, do, be; and with whom all these states should, and should not, be done. A teenager's own urge is to escape the present in order to achieve a future adulthood that is largely fantastical. And so, the well-intentioned foresight of adults tries to capture the emerging futures of anticipatory teenagehood but rushes headlong into a shared space of shared, stubborn antagonisms. Such that a 'we-know-best' based upon experience borne of habit - an anaesthetized form of living, philosopher Vilém Flusser reminds us (2002) - comes up against an anticipation borne of a deeply felt urge for creative becoming.

Our example from 1978 - the song She's So Modern by the Irish punk/new wave band The Boomtown Rats - constructs an embodiment of the modern, 
presents the modern itself as new human productive capacity of embodied, materialized interpretation: an interpretation of signs that becomes its own anticipation of a world. ${ }^{3}$ Being modern is different from being contemporary, however. We will see these differences in stance develop via Agamben (2008), who is himself developing the contemporary from Friedrich Nietzsche's concept of the 'untimely' (1997). Briefly, in Nietzsche's Untimely Meditations (1997), 'On the Uses and Disadvantages of History for Life', untimeliness is an ontological attitude necessary to adopt in order to account for history in such a way as to develop a future-focused present. There is a passage in which he links explicitly anticipation, creativity and life:

If the historical drive does not also contain a drive to construct, if the purpose of destroying and clearing is not to allow a future already alive in anticipation to raise its house on the ground thus liberated, if justice alone prevails, then the instinct for creation will be enfeebled and discouraged.

(Nietzsche, 1997, p. 95) ${ }^{4}$

For Nietzsche here, anticipation of possible futures remains in the present as potential and needs access to a creative power in order for the encrustations of the present to be cleaned away. Not only this, but creativity itself is enabled by such a ground-clearing; or should be for these futures to emerge living, vital, vivid, even exuberant [lebendige]. Nietzsche is almost breathless in this passage. This is important: anticipation and hope, life and joy, clearing and creating; better futures and presents as the normative outcome of an untimely history. Agamben works with this approach to develop an ontology of the contemporary; he takes this untimeliness into the present, as an attitude to the present. We, in turn, take this contemporary back to the future.

So, now, back to 1978. The Boomtown Rats' She's So Modern from that year, a punk/new wave ${ }^{5}$ vision of modernity, disruption and semiotic limits. The modern girl knows much: what to wear, what to say, what is important art (Dada, by the way) and the difference between sexual fetishism and right-wing politics. ${ }^{6}$ This captures a sense of its time wrapped in the garb of the modern. 'She' is the pinnacle of the twentieth century: symbolized by the 1970s, captured in the rhythm and styling of 1978. 'She' is the spirit of her time; 'she' is 'a modern girl'. The 'modern' is a girl, with language. There is an important moment when the narrative is disrupted by lang-ga-ga-ga-guage in an utterly Artaudian manner (Deleuze and Guattari, 1984, 1994) - the singer/storyteller escapes from the constraints of the story to interject this anti-linguistic refrain. This, alongside the opening 'la-la-la-la-la', serves to punctuate the characterization; and which, along with the snarled tone of the delivery by singer Bob Geldof, takes us listening (and so implicated in the storytelling) to a place outside the modern and the modern girl. This is critique (and John O'Reilly in his chapter in this volume names this critical space and time, 'OtherWise'). A critical declamation that is delivered in the opening of the song in lines that also form the chorus: stated up-front and repeated throughout. 
But 'she' has limits to her becoming - in both the archaic judgemental ('becoming' as 'charming') and ontological senses. These limits are the very fact of her modernity. 'She' remains, stuck in the 1970s, in 1978; 'she' is fixed and, now because of this, already out-of-date. From a certain perspective, 'she' is too right, 'she' fits too well, 'she' accommodates the given of a moment rather than shapes it. Any anticipation that remains is regularized as the active configuring of signs, materials and strategy. It merely registers and makes something different, gets ready; it is standardized according to the 'right' clothes and the 'right' codes. This future of the being-modern is identical and predictable; it is the same as before. What every teenager secretly knows, and deeply fears, are the mechanisms whereby the expressions of their own anticipation are captured, rendered semiotically meaningful, made modern and socially stable, situated and tamed. 'Her' being modern is the mark of her archaism; 'she' is no longer our now, because 'she' is only 'her' 'now'; 'she' is forever 'now' in 1978. That is where she belongs. ${ }^{7}$

The other option to being so modern and therefore so out-of-date, is to belong to a time but to no longer 'coincide with it' or 'adjust [. . .] to its demands', Agamben (2008, p. 41). That is, it is to be contemporary.

\section{The contemporary}

In his essay 'What is the contemporary?' (2008) Agamben initially examines the question via Nietzsche's concept of the untimely - though other philosophers, poets and fashion designers (among others) are encountered - in order to position his own evaluation of the models of time, untimeliness and, of course, contemporariness. Agamben's characteristic erudition allows him to gather these concepts together with particular attention to the relationship between past and present, between historical and contemporary times. This is done not simply to scrape Nietzsche's bones for his best concepts ${ }^{8}$ but to take them and put them back into play in another time, to do related but different types of work, to experience them anew and experiment with them to create novel concepts. Similarly, our intention is to replay Agamben's conception of the contemporary in such a way that it can be mobilized within anticipatory futures thinking (Rosen and Kineman, 2005; Poli, 2010, 2017; Rossel, 2010; Rosen, 2012; Roubelat, 2016). We will argue that Agamben's and Nietzsche's attitudes of contemporary untimeliness can be as equally directed towards the future in its relation to the present, as they can to the past and its relation to the present.

We have noted that Poli (2010) engages with some philosophical work: he focuses upon Edmund Husserl (1991) and Ernst Bloch (2000). While Husserl's phenomenology and some of its subsequent adherents are discussed in terms of the relationship between consciousness and the future, Poli $(2010$, p. 8) attends more to Bloch's work on hope as an ontology of the future in terms of open categories (that is, categories that are only partially determined). In Chapter Five of his Introduction to Anticipation Studies, 'Anticipation in Philosophy' 
(2017, pp. 77-100), Poli extends his philosophical focal points much further: fixing again upon Ernst Bloch and, a philosopher on whom Poli is expert, Nicolai Hartmann. The other twentieth-century philosophers Poli exemplifies in this chapter are: Bergson, Husserl, George Mead, Whitehead, Peirce, Hans Jonas, Heidegger and Deleuze. With regard to those philosophers from this list with whom we are most familiar - Whitehead and Deleuze - Poli gives Deleuze short shrift: confessing that he 'may have grossly misunderstood Deleuze - his language is notoriously obscure' (Poli, 2017, p. 88). Whitehead's process philosophy and its speculative metaphysics, however, is much closer to Poli's position, he admits (2017, pp. 82-85). We will need to investigate Poli, Whitehead and anticipation another time, but will note here that there is more to offer from Deleuze's philosophy to anticipation, especially with regard to his (Deleuze, 1993) reworking of Whitehead's concept of the event. (We note, also, that Nathaniel Barron writes on Bloch in this volume.) For us, a turn to Agamben (and Nietzsche) offers another direction to the future, one that steers close to the philosophy of Deleuze insofar as it focuses upon life, ontology and creativity (Holland, 2009).

In Agamben, the issue of ontology is no less important than in Husserl, for example. But his is characterized differently. Agamben's focus is not haunted by epistemological concerns, paring away experience to arrive at a pure, clear subjective truth, but is primed by an ontology of creation that aims to accentuate the creative potentialities available to us all. For us, such a creative approach to considering the changes that define being in all its modes - often referred to as becoming or ontogenesis - is also one that incorporates an attitude to the future. ${ }^{9}$ Agamben outlines four key modes of being contemporary: to stand outside one's time; thus, to be able to perceive the darkness of one's time; to have the courage to act upon one's time; and so, to recognize the modern as archaic. We will take them in order.

\section{The contemporary stands outside}

First, to be contemporary requires the ability to stand outside of one's age - we have noted this already in relation to the modern and The Boomtown Rats. Agamben (2008, p. 40) writes:

Those who are truly contemporary, who belong to their time, are those who neither perfectly coincide with it nor adjust themselves to its demands. They are thus in this sense irrelevant. ${ }^{10}$ But precisely because of this condition, precisely through this disconnection and this anachronism, they are more capable than others of perceiving and grasping their own time.

The modern legislates the difference between the relevant and irrelevant, the light and dark, by configuring the relationships between power and value: determining what counts as significant; identifying what an organization needs to attend to and the ways it must perform to reach those goals. The 
contemporary, as Agamben shows here, can occupy a position that enables a more creative and critical response to their time: they are more 'capable', they can 'perceive' and 'grasp' on the basis of their perception. It becomes important, then, to foster anachronism and irrelevance as attitudes whereby new perceptions can be created. They are difficult skills, skills of difficulty perhaps; because to be outside the given time means engagement and entanglement with change and the new, rather than fitting in, being relevant, being modern. In his breakdown of anticipation into 'explicit' and 'implicit', Roberto Poli argues that the awareness of explicit anticipation that guides decisions and choices, avoiding harm and threat, is efficient both in directing and keeping focus on a clear goal. However, there is a blind spot to this apparently rational approach, a blind spot whose territory is located by the term 'relevance'. Relevance, here, Poli defines as cognitive:

focused goal-oriented behavior usually gives rise to inattentional [sic] blindness, i.e. the incapacity to perceive things that are in plain sight [ . . ]. Patterns constrain attention, govern the boundary of relevance, and they direct attention to pre-established foci. The more efficient the patterns, the more likely is the outcome of an over-restricted focus of attention. The more efficient the behavioral patterns are, the more rigid they become.

(Poli, 2010, pp. 12-13)

For us, exceeding this 'boundary of relevance' is an affective act of ontological derangement, expressed and experienced in an 'untimely' fashion as 'contemporary'. Riel Miller argues similarly for scenario work as an escape route from the probabilistic approach of futures work built around a vision of epistemological efficacy, rather than the ontological awareness of uncertainty that may deliver valuable insight into the future. We would go even further to argue that an 'ontological awareness of uncertainty' is a criterion of valuable insight. Miller writes:

the 'scenaric stance' achieves something that so far has largely escaped the futures studies community - the combination of a focus on the 'capacity to be free' [...] and a decisive break with the 'probabilistic stance' on the basis of an ontological rather than epistemological point of departure.

(Miller, 2011, p. 25)

Just as with Miller's 'scenaric stance', we propose creative nondeterminism as a material act of fabricating a contemporary experiential space. This is an ontological space of immanent generative criticality, which enables, and is enabled by, the transformation of value through a two-step practice of critical-analytic decoding and speculative-creative anticipation.

Agamben's first move, then, appears to give temporal form to the classic Outsider (Wilson, 1956; and re-appraised, Jay, 2007). But the contemporary does not simply stand outside of their own time, either through their own 
will or dismissed by others as an irrelevance: their very difference allows them to have a particular hold on their epoch. The contemporary does not give up on their time, but stands outside in order to make a difference, a difference that The Boomtown Rats' 'modern girl' is unable to make because she coincides, to use Agamben's words, 'too well with the epoch'. He continues 'those who are perfectly tied to it in every respect, are not contemporaries, precisely because they do not manage to see it; they are not able to firmly hold their gaze upon it' (Agamben, 2008, p. 41). Thus, for Agamben, we have the contemporary regarding its epoch from the status of an anachronism. ${ }^{11}$ For, just as they do not belong to their time, so their time does not belong to them; their 'now' is pushed away from them as they are dissociated from it in the double movement of anachronism and irrelevance. But they care, as we will see.

\section{The contemporary perceives the darkness of its time}

Agamben's second characterization of the contemporary takes this dissociation further. This disconnection from the age in which the contemporary is still interested provides a perspective on particular aspects of the times that those of us rooted in them do not easily see. Agamben (2008, pp. 44-45) writes:

But what does he who sees his time actually see? What is this demented grin on the face of his age? I would like at this point to propose a second definition of contemporariness: The contemporary is he who firmly holds his gaze on his own time so as to preserve not its light, but its darkness. [. . .] The ones who call themselves contemporary are only those who do not allow themselves to be blinded by the lights of the century, and so manage to get a glimpse of the shadows in those lights, of their intimate obscurity.

The dark, the obscured and excluded become the focus of the contemporary. The Boomtown Rats' poor 'modern girl' is so blinded by the light of the age that 'she knows the right things to say' and 'the right clothes to wear'. But the contemporary is not blinded by the given codes, by what the modern makes relevant for seeing. The contemporary is beyond the modern simplicity of right and wrong, or the repeated pattern recognition of the habituated and anaesthetized. The contemporary is able to engage with the darkness of the times, ${ }^{12}$ with the complexity that is otherwise obscured by correct vision, noticing the light only for the shadows it casts. The critical position constructed by the contemporary is not one for its own sake only. It is not epistemologically focused, for it has nothing to do with meaning or interpretation; neither is it instrumental, with tools that grant better access to the relevance of the modern. In these ways, too, the contemporary is anticipatory. The sheer ontological weight expressed through this dissociation and attraction to the darkness is palpable. 
Being critical, then, both constructs the contemporary and enables a point from which to act with future orientation. The darkness 'concerns' the contemporary and 'never ceases to engage' him (Agamben, 2008, p. 45). The concept of criticality we will return to below when discussing Nietzsche's untimely, in his context of 'critical history', but we can note that for Agamben being critical - and its cognate terms 'critique' and 'crisis' - play an important role in taking political action. ${ }^{13}$

Similarly, the concept of 'concern' is one that is playing a role in current thinking and practice of philosophy of design - most notably, through the work of Bruno Latour (2008). Here a concern is not simply a worry, but a call to action, as Whitehead (1967, pp. 176 and 180) explains. For us, these concepts come together in an intriguing way. Contemporaneity allows for a distancing from the present in order to uncover the critical and crisis-inducing moments of its darkness and thence to act. This is an important consideration and one that brings us close to anticipation, insofar as a future-caused concern leads to (creative) action in the present. To which we will return later.

\section{The contemporary has the courage to act}

Thirdly, for Agamben, the contemporary is characterized by a certain sense of 'courage'. He explains:

to be contemporary is, first and foremost, a question of courage, because it means being able not only to firmly fix your gaze on the darkness of the epoch, but also to perceive in this darkness a light that, while directed towards us, infinitely distances itself from us [as happens with the light from distant galaxies, moving too fast away from us ever to reach us].

(Agamben, 2008, p. 46)

The courage to act creatively comes through strongly in this passage. It is not enough simply to recognize darkness in order to lead to action. Acting as a contemporary is not a simple decision, it requires bravery and resolution both to engage with darkness and find the moments upon and within which to act. These moments emit as lightness, photonic beams that can take us, if we are brave enough, on a voyage into and out of the now. For Agamben, such slippage across time in relation to the present, is exemplified well in fashion, which actively provides for time a 'peculiar discontinuity that divides it according to its relevance or irrelevance, its being-in-fashion or no-longer-being-infashion' (Agamben, 2008, p. 47). This is different to 'knowing the right clothes to wear', of course.

This 'peculiar discontinuity' is interesting, especially to those of us working in innovation. We are well aware of the term 'disruptive innovation', coined by Clayton Christiansen (1997) to describe a technology that is dragged from the past to produce a disjunction of present processes, allowing companies to take a technology out of time to enter, or even define, new areas for business, 
or new markets to ply. Indeed, the notion of disruption has become something of a cliché, something required, legislated. ${ }^{14}$ Nevertheless, there is a way in which we can consider disruption, or any radical discontinuity of innovation, as the (strategic) creation of the becoming contemporary of technology (or any product, service or process). One would imagine, then, that any originators of a particular technology might require a degree of courage, as they face an uncertain future however well they might have mapped it strategically. This is to introduce a future-focus a little early in our piece, however. So, we might consider any organization finding an old technology (or process, product or service) to rework to a different present (different from the perspective of the technology, and so on, that is) as courageous, critical historians of the type articulated by Nietzsche; who writes:

Men and ages which serve life by judging and destroying a past are always dangerous and endangered men and ages. For since we are the outcome of earlier generations, we are also the outcome of their aberrations, passions and errors, and indeed their crimes; it is not possible wholly to free oneself from this chain.

(Nietzsche, 1997, p. 76)

Nietzsche's untimely man recognizes the darkness in the present, in himself: as dangerous and endangered and generated from the abnormalities, mistakes and even crimes of the past. That crisis and criticality for which Agamben's contemporary requires courage is for Nietzsche's untimely a service for life. It may be a step too far to imagine that organizations panning for the next disruptive innovation, as for specks of gold in the mud, are courageous contemporaries. (Maybe we could give them the benefit of the doubt? Or, maybe, innovators and the novelty they strive for are never quite irrelevant enough.)

The contemporary, then, serves the now by being outside it, recognizing its faults, its deviations, its dangerous crises and is called to act by them, by the flashes of light in the midst of the darkness. A fashionable slippage from time proves to be an immensely creative response to it. Agamben (2008, p. 49) explains further:

the 'now,' the kairos ${ }^{15}$ of fashion is ungraspable: the phrase, 'I am in this instant in fashion' is contradictory, because the moment in which the subject pronounces it, he is already out of fashion. So, being in fashion, like contemporariness, entails a certain 'ease,' a certain quality of being outof-phase or out-of-date, in which one's relevance includes within itself a small part of what lies outside of itself, a shade of démodé, of being out of fashion.

Here we see, added to courage, 'a certain ease' in encompassing (but not exhaustively, or as an act of homogenization or totalization) relevance and irrelevance, being in and out of fashion, of grasping the ungraspable, to disrupt 
as a service to life, being concerned (as a call to action) about crises. We can now consider Agamben's fourth, and final, characteristic of the contemporary: in the production of the archaic.

\section{The contemporary sees the present as archaic}

Finally, we have the fourth and last characteristic of being contemporary. Agamben tells us that it involves the creation of the present as archaic, the recognition of the 'modern and recent' as archaic. At the same time as the contemporary dislocates from the space and the time of the now and acts both against and for it, it is located as archaic. This is not a simple distancing however; as we have seen, the contemporary also is expressed in terms of being-out-of-date, outside of now, irrelevant. In the production of the present as archaic, therefore, we have the simultaneous disruption of present time and location of untimely beings as critical (that is, in relation to crises) and creative acts. This is dangerous, for the judgement upon the now destroys it by repositioning it as archaic. The doubling back of this danger upon the contemporary person, Agamben highlights, is because the archaic situates the arkhe (å $\rho \chi \eta \dot{)}$, the origin, not only of our present, but of our contemporary too. Criticality becomes self-oriented and recognizes that little bit of irrelevance inside the contemporary. Dangerous and endangered the untimely contemporary person may be, but its approach to crisis is creative and is one that is angled resolutely to, or as an anticipatory 'from', the future. At this moment, it is worth noting Agamben's final sentence of this essay, for it brings us to a point where he not only reflects upon the value of his words, but in so doing, anticipates their possible future significance; it runs as follows:

It is on our ability to respond to this exigency and this shadow, to be contemporaries not only of our century and the 'now,' but also of its figures in the texts and documents of the past, that the success or failure of our seminar depends.

(Agamben, 2008, p. 54)

'Success or failure' depend upon a number of varying plausible, possible or, maybe, even probable futures that remain contingent upon the differing contexts of their reception of Agamben's work. There is a sense in which Agamben's essay, 'our seminar', is itself contemporary: standing outside of its moment of creation and delivery, with the power to produce its own devastating critique, for it may well fail. 'Success' may come from Agamben's work engendering multiple future contemporaries; that it becomes both relevant and irrelevant, in and out of time, even fashionable and not, all at the same un-time.

The contemporary, as elucidated by Agamben, as the figure, emblem and embodiment of anticipation is deeply problematic for businesses because it incorporates the figure of uncertainty. Not simply does the contemporary not 
look right (unlike the 'modern girl'), it creates a space of critical distance that is organizationally uncomfortable. Perhaps most uncomfortable of all, because the very visibility of the contemporary - as an alternative vision and radically different version of success - provides for any business a troublesome apparition. And doubly troublesome because the contemporary as uncertainty is an organizational signal, a commercial itch demanding a creative, disjointed and different response. The irony, of course, is that because such an organization is bound by the comforting certainty of relevance, they are incapable of becoming contemporary and the courage needed to anticipate.

\section{Anticipation and the contemporary}

In a way, the concept of the contemporary appears to point in two directions: to the present and the past. We have some work to do to draw this to the future. Luckily, for us, Agamben has provided a way into this, when he writes (2008, p. 48): 'time of fashion, therefore, constitutively anticipates itself and consequently is always too late. It always takes the form of an ungraspable threshold between a "not yet" and a "no more"" (emphasis added). We mentioned, above, how the fashionable contemporary is able to enter into and remove itself from present time and able to make critical comments about its relevance and irrelevance. For Agamben, this exemplified its 'courage' in the face of any darkness perceived in the current time. In this quotation, however, he introduces another temporal attitude: anticipation. Such that not only does the fashionable contemporary react to the present, it does so through a 'stance' (Miller, 2011) that relates to the future. Being 'in advance of itself places the contemporary in-between future, past and present, in and out of time. Which characterises the modalities of its ontological present, too and, we argue, is a necessary attitude of anticipation. For to describe someone (or something) anticipating is to characterise them incorporating, within themselves, a model of the future in order to reorient themselves in the present differently (Miller, 2011; Rosen, 2012; Poli, 2017; and the many others discussed in this book).

In fact, this happens in Nietzsche's work on critical history too, from which Agamben draws his own enquiry into the contemporary. In the seventh section of Nietzsche's 'On the uses and disadvantages of history for life', the second of his untimely meditations, he accentuates the future-focused, anticipatory nature of his concept of a critical history. He writes:

If the historical drive does not also contain a drive to construct, if the purpose of destroying and clearing is not to allow a future already alive in anticipation to raise its house on the ground thus liberated, if justice alone prevails, then the instinct for creation will be enfeebled and discouraged.

(Nietzsche, 1997, p. 95)

Criticality and creativity are key characteristics of the untimely and contemporary alike, in whatever way they are they are oriented. A critical creativity will 
take an empty historicism on a new journey, a future journey. But one that situates neither the historical nor the future in self-referential limits, spinning like cold, dead stars. Rather, they elucidate and provoke a present full of possibilities, of potentials, of openness, where what may become can set the terms of any present actuality.

If we are to see anticipation as being concerned with the future in order to create a different present, being engaged with the darkness of the future even, then this is in order to make an intervention today. This concern is a call to present action. Those who anticipate must simultaneously occupy a position outside their own time and see it in all its darkness - thus becoming contemporary - and do so in a manner that stands outside future possible times too. They need the courage to anticipate their own contemporariness, their own irrelevance, in order for it to be created and involved in an on-going creation. Not to be relevant is therefore an exceeding or surpassing the boundaries of any self, as philosopher Georges Bataille notes in the first of our epigrams to this chapter. As any creative anticipation challenges the accepted 'boundary of relevance' (Poli, 2010, pp. 12-13) - the given boundary of relevance in any foresight or planning process; the inevitability and necessity that pre-determines relevant outcomes; the drive for certainty in the face of uncertainty - courage is needed in adopting a critical position in relation to the darkness within the organizational, cultural, social and political paradigms within which one is situated. We cannot forget, in all of this, that Agamben's contemporary needs to be able to see the tiniest of lights amid the darkness. This is the spark to anticipate, to take up Whitehead's call to speculate, to go on an adventure. To live and create.

Imagine, then, the contemporary of 2078 outside of their time, aware of the darkness of their epoch as something unable to be lived, is experiencing the archaic attraction of a previous time, 1978 say, 2018, or even 2020 - all important moments in the course of this chapter - how might they be utterly irrelevant? Or, imagine that our contemporary of 2020 is not only experiencing the forces of uncountable prior, archaic moments on the present, but pressure from even more futures on the present felt as unliveable. Our untimely men, women and all in 2020, live in a doubly defined darkness of life that can never be lived but can be anticipated: as archaeologists of prior time and anticipators of future times.

Closing the introductory section of the second of his untimely meditations, 'On the uses and disadvantages of history for life', Nietzsche (1997, p. 60) ponders:

for I do not know what meaning classical studies could have for our time if they were not untimely - that is to say, acting counter to our time and thereby acting on our time and, let us hope, for the benefit of a time to come.

From Agamben we have seen how this thought pertains also to the contemporary, who acts upon and against and for a now. Nietzsche here emphasizes 
the value of such a position 'for the benefit of a time to come'. Would it be over-presumptuous of us to rework Nietzsche's words, slightly, to stress this future-focus even further? And so: we do not know what meaning futures studies could have for our time if they were not untimely; acting counter to and on our time for the benefit of our present. Or, in other words, aligning with the work of Agamben we have been discussing here: any courageous, critical anticipation activated to deal with a dark present, needs to model itself along the lines of the contemporary. For to be anticipatory is also to be untimely. Now, what a future.

\section{Acknowledgements}

We would like to thank Fabrice Roubelat, General Editor of the French futures journal Prospective et Stratégie, for giving us permission to use the English version of the article originally published in that journal in French: Brassett and O'Reilly (2018b). This chapter is an expanded elaboration of that article.

\section{Notes}

1 They explain:'A book has neither object nor subject; it is made of variously formed matters, and very different dates and speeds. To attribute this book to a subject is to overlook these workings of matters, and the exteriority of their relations' (Deleuze and Guattari, 1988, p. 3).

2 We are aware that an aspect of Deleuze and Guattari's creative approach to writing $A$ Thousand Plateaus is to move away from the standards of book production and to regard their chapters as 'plateaus', with many different strands passing through each of them rather than the rigid, linear connections between their conclusions and introductions. We use 'chapters' not to undo their argument about disrupting the writing of totalizing books, but to keep attention on our narrative.

3 We are trying not to encounter the concept of 'modernity' and its vast sociological and cultural studies literature. This seems to approach a different set of concerns, issues and agencies than those of this chapter. For work on modernity in a number of registers, see: Appadurai (1996) and Giddens (1991).

4 A more literal translation would be: 'When, behind the historical drive, there is no drive to build, when destroying and clearing does not liberate a ground upon which to build a future already alive in hope, when justice alone is done, then the creative instinct will be invalidated and discouraged [Wenn hinter dem historischen Triebe kein Bautrieb wirkt, wenn nicht zerstört und aufgeräumt wird, damit eine bereits in der Hoffnung lebendige Zukunft auf dem befreiten Boden ihr Haus baue, wenn die Gerechtigkeit allein waltet, dann wird der schaffende Instinkt entkräftet und entmutigt]' (Nietzsche, 1954, \$7). Thanks to Joanna Brassett for help with this translation.

5 We mention punk in terms of subcultural style in our article on design and scenario planning, Brassett and O'Reilly (2015), with reference to the seminal work on this topic Hebdige (1979). We note that Muggleton (2000) provides a more recent engagement with similar themes. See also: Sklar (2013), for a US perspective on punk style expressed through fashion; and Savage (1991) for a UK focus covering many of its cultural forms.

6 Interestingly, one of the modern girls mentioned in the song is described as a performer, comedian, who wants to be a photograph. Pop songs about celebrity and being watched seem to have been popular in 1978: along with She's So Modern, there was another New Wave song, by Scottish band The Rezillos Top of the Pops (the title references a popular music television show in the UK at the time) and Kraftwerk's The Model. 
7 Later in the song, 'she' is described as joyfully painting moustaches on herself, with the explanation that 'she' loves the Mona Lisa. With moustaches, 'she' identifies with an earlier twentieth-century act of Punk Rock/Dada. 'She' becomes 'he' - hence our use of inverted commas.

8 As Deleuze and Guattari explain (1994, p. 83; interestingly, in relation to Nietzsche) of a certain sort of lazy philosophizing: 'Nothing positive is done, nothing at all, in the domains of either criticism or history, when we are content to brandish ready-made old concepts, like skeletons destined to intimidate any creation, without seeing that the ancient philosophers from whom they are borrowed were already doing what we would like to prevent modern philosophers from doing: they were creating their concepts and were not content to clean and scrape bones like the critic and historian of our time' (translation modified).

9 We have written about this with emphasis on the possible relations between design and scenario planning: Brassett and O'Reilly (2015). See also Zamenopoulos and Alexiou (2007), which gives a good overview of Rosen's work on anticipation in relation to design.

10 Agamben's original Italian is inattuale. We are intrigued with the possibilities that this word entails, and the conceptual journey it takes us through, especially in regard to terms we are discussing here. We can see some other way of dealing with the actual in Agamben's word, which would align - through Deleuze's (1991) work on Bergson - to notions of virtuality but, also, the concept of potentiality. 'Potentiality' is a term that occurs elsewhere in Agamben's work - see Agamben (1999). Further work is necessary to investigate these relationships fully.

11 As Nietzsche (1997) also argues for the untimely man. For brevity, we have not mapped in detail Agamben's dealings with Nietzsche's concept of untimely, though we have and will make some references to Nietzsche, an encounter with his relevant work will need to come another time.

12 As may be possible by a philosopher like Hannah Arendt. Brassett (2021) writes an entry titled 'Creativity' for the book Designing in Dark Times. An Arendtian Lexicon. Agamben, we should note, is influenced by Arendt, particularly in his political philosophical writings (De Boever, 2016, pp. 237-238); see: Agamben (1998).

13 We have noted this in our essay on Lucretius, the clinamen and design: Brassett and O'Reilly (2018a). We should also note that we recognise the way in which Whitehead characterises 'critical philosophy', favouring rather 'speculative philosophy'. This will need proper investigation in relation to anticipation and the contemporary another time but, for now, we include this: 'The divergence between the two schools [critical and speculative] is the quarrel between safety and adventure' (Whitehead, 1966, p. 173). The adventurous Whitehead is always contemporary (Stengers, 2011, p. 18).

14 Editors' note. See O'Reilly's chapter in this volume for more on disruption and its critique.

15 Liddell and Scott $(1889$, p. 392) have four entries for kairós (кaıрó)). The third, of time, defines it as: 'the right point of time, the proper time or season of action, the exact or critical time'.

\section{References}

Agamben, G. (2008) 'What is the Contemporary?', in Agamben, G. (ed.), What Is an Apparatus? and other Essays. Trans. D. Kishik and S. Pedatella. Stanford, CA: Stanford University Press, pp. 1-24.

Agamben, G. (1999) 'On Potentiality', in Agamben, G. (ed.), Potentialities. Collected Essays in Philosophy. Trans. D. Heller-Roazen. Stanford, CA: Stanford University Press, pp. 177-184. 
Agamben, G. (1998) Homo Sacer: Sovereign Power and Bare Life. Trans. D. Heller-Roazen. Stanford, CA: Stanford University Press.

Appadurai, A. (1996) Modernity at Large: Cultural Dimensions of Globalization. Minneapolis, MN: University of Minnesota Press.

Bloch, E. (2000) The Spirit of Utopia. Trans. A.A. Nassar. Stanford, CA: Stanford University Press.

Brassett, J. (2021) 'Creativity' in Staszowski, E. and Tassinari, V. (eds.), Designing in Dark Times. An Arendtian Lexicon. Series: 'Designing in Dark Times'. New York and London: Bloomsbury, pp. 99-103.

Brassett, J. and O'Reilly, J. (2018a) 'Collisions, Design and the Swerve', in Vermaas, P. and Vial, S. (eds.), Advancements in Philosophy of Design. Series: Design Research Foundations. Cham, Switzerland: Springer, pp. 71-98.

Brassett, J. and O'Reilly, J. (2018b) 'Retour à 2078: Réflexions sur l'anticipation et le contemporain', Revue de Prospective et Stratégie, 9, Édition Spéciale 'Voir Loin', (December), pp. 11-22.

Brassett, J. and O’Reilly, J. (2015) 'Styling the Future. A Philosophical Approach to Design and Scenarios', Futures, 74, pp. 37-48.

Christensen, C. (1997) The Innovator's Dilemma. When New Technologies Cause Great Firms to Fail. Cambridge, MA: Harvard Business Review Press.

De Boever, A. (2016) Plastic Sovereignties. Agamben and the Politics of Aesthetics. 'Incitements' Series. Edinburgh: Edinburgh University Press.

Deleuze, G. (1993) The Fold. Leibniz and the Baroque. Trans. T. Conley. London: Athlone Press.

Deleuze, G. (1991) Bergsonism. New York, NY: Zone Books.

Deleuze, G. and Guattari, F. (1994) What is Philosophy? Trans. G. Burchill and H. Tomlinson. London: Verso Books.

Deleuze, G. and Guattari, F. (1988) Capitalism and Schizophrenia 2. A Thousand Plateaus. Trans. B. Massumi. London: Athlone Press.

Deleuze, G. and Guattari, F. (1984) Capitalism and Schizophrenia 1. Anti-Edipus. Trans. R. Hurley, M. Seem and H.R. Lane. London: Athlone Press.

Flusser, V. (2002) 'Habit: the true aesthetic criterion', in Writings. Ed. A. Ströhl, trans. E. Eisel. Minneapolis, MN: University of Minnesota Press, pp. 51-57.

Giddens, A. (1991) Modernity and Self-Identity. Self and Society in the Late Modern Age. London: Polity Press.

Hebdige, D. (1979) Subculture. The Meaning of Style. New Accents Series. London: Methuen.

Holland, E. (2009) 'Introduction. Image, Text, Thought', in Holland, E.W., Smith, D.W. and Stivale, C.J. (eds.), Gilles Deleuze: Image and Text. London and New York, NY: Continuum Books, pp. 1-6.

Husserl, E. (1991) On the Phenomenology of the Consciousness of Internal Time (1893-1917). Trans. J.B. Brough. Heidelberg: Springer Netherlands.

Jay, M. (2007) 'Still Sleeping Rough: Colin Wilson's The Outsider at Fifty', Salmagundi, 155/156, (Summer-Fall), pp. 3-12.

Kraftwerk (1978) 'Das Model' (The Model), Die Mensch Maschine [vinyl, 1 C 058-32 843]. Köln: EMI Electrola Gmbh.

Latour, B. (2008) 'A Cautious Prometheus? A Few Steps Toward a Philosophy of Design (with Special Attention to Peter Sloterdijk)', in Hackney, F., Glynne, J. and Minton, V. (eds.), Networks of Design. Proceedings of the International Conference of the Design History Society. Boca Raton, FL: Universal-Publishers, pp. 2-10. 


\section{6}

Jamie Brassett and John O'Reilly

Liddell, H.G. and Scott, R. (1889) An Intermediate Greek-English Lexicon. Oxford: Oxford University Press.

Miller, R. (2011) 'Being without Existing: The Futures Community at a Turning Point? A Comment on Jay Ogilvy's "Facing the Fold”, Foresight, 13(4), pp. 22-34.

Muggleton, D. (2000) Inside Subculture. The Postmodern Meaning of Style. Dress, Body, Culture Series. London and New York, NY: Berg.

Nietzsche, F. (1997) Untimely Meditations. Ed. D. Breazeale. Trans. R.J. Hollingdale. Cambridge: Cambridge University Press.

Nietzsche, F. (1954) 'Vom Nutzen und Nachteil der Historie für das Leben', Unzeitgemäße Betrachtungen. Available at: http://www.zeno.org/nid/20009229833 (Accessed: 8 May 2020).

Poli, R. (2017) Introduction to Anticipation Studies. Series: 'Anticipation Science', vol. 1. Berlin: Springer.

Poli, R. (2010) 'The Many Aspects of Anticipation', Foresight, 12(3), pp. 7-17.

Rosen, J. and Kineman, J.J. (2005) 'Anticipatory Systems and Time: A New Look at Rosenean Complexity', Systems Research and Behavioral Science, 22, pp. 399-412.

Rosen, R. (2012) Anticipatory Systems: Philosophical, Mathematical and Methodological Foundations, 2nd edn. London: Pergamon Press.

Rossel, P. (2010) 'Making Anticipatory Systems More Robust', Foresight, 12(3), pp. 72-85.

Roubelat, F. (2016) 'Anticipation et scenarisation de l'innovation. Enjeux, mise en œuvre, perspectives', Prospective et Stratégie, 7, pp. 125-139.

Savage, J. (1991) England's Dreaming. Sex Pistols and Punk Rock. London: Faber and Faber Ltd.

Sklar, M. (2013) Punk Style. 'Subcultural Style' Series. London and New York, NY: Bloomsbury Publishing Ltd.

Stengers, I. [2002] (2011) Thinking with Whitehead. A Free and Wild Creation of Concepts. Trans. M. Chase. Cambridge, MA and London: Harvard University Press.

The Boomtown Rats (1978) She's So Modern [vinyl, LUN715]. Dublin: Mulligan Records. The Rezillos (1978) Top of the Pops [vinyl, SIR 4001]. London: WEA Records Ltd.

Whitehead, A.N. [1933 (1967)] Adventures of Ideas. New York, NY: The Free Press.

Whitehead, A.N. [1938] (1966) Modes of Thought. New York, NY: The Free Press.

Wilson, C. (1956) The Outsider. London: Victor Gollancz Ltd.

Zamenopoulos, T. and Alexiou, K. (2007) 'Towards an Anticipatory View of Design', Design Studies, 28, pp. 411-436. 